Reprinted with permission from: Weed Science. 1990. 38(6):471-474.

Published and copyrighted by: Weed Science Society of America. http://www.wssa.net

\title{
Effect of temperature on picloram absorption and translocation in leafy spurge (Euphorbia esula) $)^{1}$
}

\author{
RODNEY G. LYM and CALVIN G. MESSERSMITH \\ The authors are Assoc. Prof. and Prof., Crop and Weed Sci. Dep., N.D. State Univ., Fargo, ND 58105.
}

\begin{abstract}
:
Temperature changes prior to picloram application affects its activity in leafy spurge. Absorption of ${ }^{14} \mathrm{C}$-picloram was directly correlated with temperature changes; each $1^{\circ} \mathrm{C}$ increase in air temperature 24 hours before treatment resulted in a $1 \%$ increase of ${ }^{14} \mathrm{C}$-picloram absorption in leafy spurge and vice versa. The greatest ${ }^{14} \mathrm{C}$-picloram absorption averaged $47 \%$ of applied ${ }^{14} \mathrm{C}$ when the temperature increased from $18^{\circ} \mathrm{C}$ to $24^{\circ}$ or $30^{\circ} \mathrm{C} 24$ hours before treatment compared to $33 \%$ when temperatures were constant. Translocation of ${ }^{14} \mathrm{C}$-picloram was more sensitive than absorption to temperature changes with 4.3 and $1 \%$ of applied ${ }^{14} \mathrm{C}$-picloram translocated to the roots when the plants were maintained at $12^{\circ}$ and $30^{\circ} \mathrm{C}$, respectively. Even though absorption increased directly with temperature, ${ }^{14} \mathrm{C}$-picloram translocation to the root system declined as temperature increased.
\end{abstract}

\section{Nomenclature:}

Picloram, 4-amino-3,5,6-trichloro-2-pyridinecarboxylic acid; leafy spurge, Euphorbia esula L. \#² EPHES.

\section{Additional index words:}

Environment, pasture and rangeland weed control, EPHES.

\footnotetext{
${ }^{1}$ Received for publication October 7, 1989, and in revised form June 28, 1990. Published with the approval of the Director, Agric. Exp. Stn., N.D. State Univ. as J. Art. No. 1812.

${ }^{2}$ Letters following this \# symbol are a WSSA-approved computer code from Composite List of Weeds, Revised 1989. Available from WSSA, 309 West Clark Street, Champaign, IL 61820.
} 


\section{Introduction}

Picloram is the most effective and commonly used herbicide for leafy spurge control $(1,5,6)$. Picloram generally is most effective when applied during the true-flower growth stage in mid-June or during fall regrowth occurring from late August until a killing frost in October. In North Dakota, picloram at 1.1 to $2.2 \mathrm{~kg}$ ae ha ${ }^{-1}$ generally provides 70 to $90 \%$ leafy spurge control for 18 to 24 months after treatment (7). However, control by picloram can be inconsistent and occasionally has been $5 \%$ or less 2 months after application even when properly applied at $2.2 \mathrm{~kg} \mathrm{ha}^{-1}(6)$.

Herbicide absorption generally increases with increasing temperature (12). Rapid movement of herbicide away from the site of penetration at high temperatures may cause increased herbicide absorption (14). Increased picloram and 2,4-D [(2,4-dichlorophenoxy)acetic acid] absorption with increasing temperatures has been shown in many species $(4,12,14)$. However, the effect of temperature on translocation is less clear. Translocation of 2,4,5-T [2,4,5-trichlorophenoxy)acetic acid] in mesquite [Prosopis juliflora (Sw.) DC.] was inhibited at very warm $\left(38^{\circ} \mathrm{C}\right)$ temperatures (10). Brady (2) reported increased 2,4,5-T translocation to the roots of four woody species with increasing temperature, but the greatest translocation in three species occurred at the coolest $\left(13^{\circ} \mathrm{C}\right)$ temperature.

Environmental conditions, especially relative humidity and air temperature, may affect picloram efficacy on leafy spurge. Absorption and translocation of ${ }^{14} \mathrm{C}-$ picloram was increased when it was applied at high (90 to $95 \%$ ) compared to low (20 to $30 \%$ ) relative humidity and when the humidity remained high at least 24 hours after treatment (11). However, absorption and translocation were similar when leafy spurge was preconditioned at high or low temperatures $\left(30 / 18^{\circ}\right.$ or $18 / 10^{\circ} \mathrm{C}$ day/night) for 48 hours prior to treatment and was not influenced by posttreatment temperature.

Root-soluble carbohydrate content of leafy spurge varied inversely with changes in the 6-day mean air temperature (8). Soluble carbohydrate content quickly increased as the temperature decreased but declined rapidly as the mean temperature increased. Because carbohydrate movement in leafy spurge apparently is affected rapidly (24 hours or less) by changes in air temperature, a change in temperature prior to picloram application may influence herbicide translocation to the roots.

Occasional poor leafy spurge control by picloram may be due to application during periods of temperature fluctuation adverse to picloram absorption and translocation. The purpose of this research was to evaluate picloram absorption and translocation in leafy spurge as affected by changes in air temperature prior to application.

\section{Materials and methods}

Leafy spurge plants were propagated from one accession (1984 ND 001$)^{3}$ that originally was obtained from a natural infestation near Fargo, ND. Stem tips about $3 \mathrm{~cm}$ long

\footnotetext{
${ }^{3}$ Registry of leafy spurge accessions maintained by David G. Davis, USDA Biosciences Res. Lab., Fargo, ND 58105.
} 
were cut from the parent clones, all but the upper three to four leaves were removed, and the basal stem was dipped in a commercial mixture of $0.2 \% 1$-naphthaleneacetic acid. Each cutting was planted into a $4-\mathrm{cm}-$ diam by $20-\mathrm{cm}-$ long conical pot, which contained a soil-less medium of peat, perlite, and vermiculite. Plants were grown in the greenhouse at $24^{\circ}$ to $27^{\circ} \mathrm{C}$ with supplemental light $\left(400 \mu \mathrm{E} \mathrm{m}^{-2} \mathrm{~s}^{-1}\right)$ when necessary for a 16 -hour light and 8-hour dark photoperiod.

Approximately 6 weeks later, the topgrowth was removed at the soil surface, and one stem per pot was allowed to regrow to the mid- to late-vegetative growth stage (15 to 20 $\mathrm{cm}$ tall) before treatment. Foliar absorption and translocation of ${ }^{14} \mathrm{C}$-picloram were greatest at this growth stage compared to the early vegetative or flowering stages in previous research (11).

Leafy spurge plants were transferred from the greenhouse to growth chambers 1 week before treatment. The chambers maintained a 45 to $60 \%$ relative humidity and a 16 -hour light $\left(700 \mu \mathrm{E} \mathrm{m}^{-2} \mathrm{~s}^{-1}\right)$ and 8-hour dark photoperiod. The initial temperature was 12,18 , $24^{\circ}$, or $30^{\circ} \mathrm{C}$, and then was held constant or changed by moving the plants to the appropriate chamber according to the following regime: a) a constant temperature 96 hours before treatment until 72 hours after treatment; b) a constant temperature from 96 hours until 24 hours before treatment, then increased by $6^{\circ}$ or $12^{\circ} \mathrm{C}$ and maintained until 72 hours after treatment; or c) a constant temperature from 96 hours until 24 hours before treatment, then decreased by $6^{\circ}$ or $12^{\circ} \mathrm{C}$ and maintained until 72 hours after treatment.

One leaf, midway on the stem of each plant, received $5 \mu \mathrm{l}$ of $0.15 \%(\mathrm{v} / \mathrm{v})$ nonionic surfactant ${ }^{4}$ in $\mathrm{H}_{2} \mathrm{O}$ applied to $1 \mathrm{~cm}^{2}$ of the leaf followed immediately by $850 \mathrm{~Bq}$ of uniformly pyridyl-ring-labeled ${ }^{14} \mathrm{C}$-picloram (specific activity $623.5 \mathrm{MBq}$ mmole ${ }^{-1}$ ) in 10 $\mu 1$ of $70 \%(\mathrm{v} / \mathrm{v})$ ethanol followed by an additional $5 \mu \mathrm{l}$ of surfactant to maximize absorption.

Plants were harvested 72 hours after treatment and were separated into the treated leaf, shoot, and roots. The roots were washed with water to remove the potting medium and were sectioned into $0-$ to $4-, 4-$ to $8-$, and $8-$ to $16-\mathrm{cm}$ depths. The treated leaf was rapidly dipped 10 times into $15 \mathrm{ml}$ of scintillation fluid ' $A$ ' $[1: 1, \mathrm{v} / \mathrm{v}$, toluene: ethanol plus $5 \mathrm{~g} \mathrm{~L}^{-1}$ 2,5-diphenyloxazole (PPO) ${ }^{5}$ and $0.5 \mathrm{~g} \mathrm{~L}^{-1}$ 1,4-bis-2-(4-methyl-5-phenyloxazolyl)benzene (dimethyl POPOP) ${ }^{5}$ ], and the unabsorbed ${ }^{14} \mathrm{C}$-herbicide removed by this method was assayed using liquid scintillation spectrometry. Plant parts were dried at $60^{\circ} \mathrm{C}$ for 24 hours, and root and shoot sections were ground in a Wiley mill (No. 10 mesh) and weighed.

The treated leaf and two or more 120 - to $150-\mathrm{mg}$ root or shoot subsamples equaling at least $10 \%$ of the sample weight were each combusted in a biological tissue oxidizer. The ${ }^{14} \mathrm{CO}_{2}$ was collected in $15 \mathrm{ml}$ of scintillation fluid ' $\mathrm{B}$ ' $(10: 7: 3$, v/v/v, toluene:2methoxyethanol:ethanolamine plus $5.0 \mathrm{~g} \mathrm{~L}^{-1}$ PPO and $0.5 \mathrm{~g} \mathrm{~L}^{-1}$ dimethyl-POPOP) and assayed using liquid scintillation spectrometry. Oxidizer efficiency was determined using

\footnotetext{
${ }^{4}$ Surfactant WK (dodecyl ether of polyethylene glycol). E.I. duPont de Nemours and Co., Wilmington, DE

${ }^{5}$ Abbreviations: PPO, 2,5-diphenyloxazole; dimethyl POPOP, 1,4-bis-2-)4-methyl-5-phenyloxazolyl)benzene.
} 
methyl $-{ }^{14} \mathrm{C}-$ methacrylate, and liquid scintillation counting efficiency was determined using an external standards ratio and standard corrections.

The experiment was conducted twice and had a similar variance, so the combined data are presented. The experiment was a randomized complete block design with four replicates per treatment and had a factorial arrangement of pre- and posttreatment temperature. Data were subjected to analysis of variance and means separated using a protected LSD test.

\section{Results and discussion}

A temperature change 24 hours before treatment directly affected ${ }^{14} \mathrm{C}$-picloram absorption in leafy spurge by nearly $1 \%$ for each $1^{\circ} \mathrm{C}$ change in temperature (slope $=0.95$ ) (Table 1).

Table 1. Absorption of ${ }^{14} \mathrm{C}$-picloram in leafy spurge during various pre- and post treatment temperatures.

\begin{tabular}{|c|c|c|c|c|c|}
\hline \multirow[b]{2}{*}{ Initial temperature ${ }^{\mathrm{a}}$} & \multicolumn{5}{|c|}{$\begin{array}{l}\text { Absorption as affected by temperature }(C) \\
24 \text { hours before to } 72 \text { hours after treatment }\end{array}$} \\
\hline & 12 & 18 & 24 & 30 & Mean \\
\hline $\mathrm{C}$ & & & $\overline{f a p p}$ & & \\
\hline 12 & $34^{\mathrm{b}}$ & 31 & 34 & & 33 \\
\hline 18 & 29 & 30 & 42 & 51 & 38 \\
\hline 24 & 17 & 20 & 31 & 35 & 26 \\
\hline 30 & & 22 & 27 & 37 & 29 \\
\hline $\operatorname{LSD}(0.05)$ & & & -11 & & \\
\hline Mean & 27 & 26 & 34 & 41 & \\
\hline Regression & $\mathrm{Y}=31.4+0.95 \mathrm{X}^{\mathrm{c}}$ & & & & \\
\hline
\end{tabular}

The greatest absorption occurred when the temperature was increased from $18^{\circ}$ to $24^{\circ}$ or $30^{\circ} \mathrm{C} 24$ hours before treatment and averaged 42 and $51 \%$, respectively. Conversely, absorption averaged only $20 \%$ when the temperature was lowered $12^{\circ} \mathrm{C} 24$ hours before treatment. Absorption was similar when the temperature was held constant throughout the experiment and averaged $34^{\circ}, 30^{\circ}, 31^{\circ}$, and $37 \%$ at $12^{\circ}, 18^{\circ}, 24^{\circ}$, and $30^{\circ} \mathrm{C}$, respectively.

The amount of ${ }^{14} \mathrm{C}$-picloram in the treated leaf was higher when the temperature increased 24 hours before treatment than when it declined or remained constant (Table 2). The increase in ${ }^{14} \mathrm{C}$-picloram in the treated leaf when the temperature increased 24 hours before treatment would be expected because absorption also increased under these conditions. However, the ${ }^{14} \mathrm{C}$-picloram content increased only by one-third the amount that absorption increased (slope 0.33 vs. 0.95 ), implying the remaining ${ }^{14} \mathrm{C}$-picloram was translocated out of the treated leaf. Concentration of ${ }^{14} \mathrm{C}$-picloram was similar when the temperature remained constant throughout the experiment and averaged $6 \%$ of that applied. 
Table 2. Distribution of ${ }^{14} \mathrm{C}$-picloram in leafy spurge during various pre- and posttreatment temperatures.

\begin{tabular}{|c|c|c|c|c|c|c|}
\hline \multirow[b]{2}{*}{ Plant section } & \multirow{2}{*}{$\begin{array}{l}\text { Initial } \\
\text { temperature }^{\mathrm{a}}\end{array}$} & \multicolumn{5}{|c|}{$\begin{array}{l}\text { Absorption as affected by temperature (C) } \\
24 \text { hours to } 72 \text { hours after treatment }\end{array}$} \\
\hline & & 12 & 18 & 24 & 30 & Mean \\
\hline & $\mathrm{C}$ & 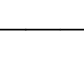 & 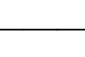 & of apr & 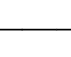 & 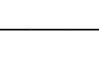 \\
\hline \multirow[t]{4}{*}{ Treated leaf } & 12 & $7^{\mathrm{b}}$ & 10 & 12 & & 10 \\
\hline & 18 & 6 & 6 & 8 & 12 & 8 \\
\hline & 24 & 5 & 6 & 6 & 10 & 7 \\
\hline & 30 & & 3 & 4 & 6 & 4 \\
\hline \multicolumn{7}{|l|}{$\operatorname{LSD}(0.05)$} \\
\hline Mean & & 6 & 6 & 7 & 9 & \\
\hline Regression & \multicolumn{4}{|c|}{$\mathrm{Y}=7.2+0.33 \mathrm{X}^{\mathrm{c}}$} & \multicolumn{2}{|c|}{$\left(\mathrm{R}^{2}=0.94\right)$} \\
\hline \multirow[t]{4}{*}{ Above treated leaf } & 12 & 4 & 6 & 5 & & 5 \\
\hline & 18 & 4 & 5 & 6 & 9 & 6 \\
\hline & 24 & 1 & 3 & 6 & 6 & 4 \\
\hline & 30 & & 2 & 5 & 9 & 5 \\
\hline $\operatorname{LSD}(0.05)$ & & & & - & 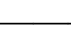 & \\
\hline Mean & & 3 & 4 & 6 & 8 & \\
\hline Regression & \multicolumn{4}{|c|}{$\mathrm{Y}=4.9+0.22 \mathrm{X}$} & \multicolumn{2}{|c|}{$\left(\mathrm{R}^{2}=0.88\right)$} \\
\hline \multirow[t]{4}{*}{ Below treated leaf } & 12 & 3 & 3 & 4 & & 3.3 \\
\hline & 18 & 3 & 2 & 2 & 3 & 2.5 \\
\hline & 24 & 1 & 2 & 2 & 1 & 1.5 \\
\hline & 30 & & 2 & 2 & 2 & 2.0 \\
\hline $\operatorname{LSD}(0.05)$ & & & & -4 & 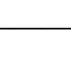 & \\
\hline Mean & & 1.7 & 2.3 & 2.5 & 2 & \\
\hline Regression & \multicolumn{4}{|c|}{$\mathrm{Y}=2.31+0.06 \mathrm{X}$} & \multicolumn{2}{|c|}{$\left(\mathrm{R}^{2}=0.63\right)$} \\
\hline Root & 12 & 4.3 & 2.8 & 2.2 & & 3.4 \\
\hline$(0$ to $16 \mathrm{~cm})$ & 18 & 2.8 & 2.5 & 3.9 & 3.1 & 3.1 \\
\hline \multirow[t]{2}{*}{ Total } & 24 & 1.5 & 1.5 & 2.1 & 1.4 & 1.6 \\
\hline & 30 & & 2.1 & 0.9 & 1.0 & 1.3 \\
\hline $\operatorname{LSD}(0.05)$ & & & & - & 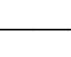 & \\
\hline Mean & & 2.9 & 2.2 & 2.3 & \multicolumn{2}{|l|}{1.8} \\
\hline Regression & \multicolumn{4}{|c|}{$\mathrm{Y}=2.23+0.045 \mathrm{X}$} & \multicolumn{2}{|c|}{$\left(\mathrm{R}^{2}=0.85\right)$} \\
\hline
\end{tabular}

${ }^{a}$ Temperature during a 72-hour period from 96 hours to 24 hours before treatment.

${ }^{b}$ Bold numbers indicate a constant temperature throughout the experiment.

${ }^{c}$ Degree temperature change 24 hour before treatment.

Translocation of ${ }^{14} \mathrm{C}$-picloram to the above treated leaf portion increased as the temperature 24 hours before treatment increased (Table 2). Maximum translocation to the above treated leaf portion of $9 \%$ of applied ${ }^{14} \mathrm{C}$-picloram occurred when the temperature was a constant $30^{\circ} \mathrm{C}$ and when the temperature increased from 18 to $30^{\circ} \mathrm{C} 24$ hours be- 
fore treatment. A decline in temperature 24 hours prior to treatment decreased the amount of ${ }^{14} \mathrm{C}-$ picloram translocated to the above treated leaf portion. For instance, 6 and $9 \%$ of applied ${ }^{14} \mathrm{C}$-picloram translocated to the above treated leaf portion at a constant temperature of 24 or $30^{\circ} \mathrm{C}$, respectively, but declined to 1 and $2 \%$, respectively, when the temperature 24 hours before treatment declined by $12^{\circ} \mathrm{C}$. Translocation of ${ }^{14} \mathrm{C}$-picloram below the treated leaf generally was not affected by an increase or decrease in temperature prior to treatment.

Translocation of ${ }^{14} \mathrm{C}$-picloram to the leafy spurge roots was greater at cool compared to warm temperatures (Table 2). The lower the initial temperature the greater the ${ }^{14} \mathrm{C}$-picloram translocation to the root. Plants maintained at $12{ }^{\circ} \mathrm{C}$ averaged $4.3 \%$ of the applied ${ }^{14} \mathrm{C}$-picloram in the roots compared to $2.5,2.1$, and $1 \%$ when plants were maintained at $18^{\circ}, 24^{\circ}$, and $30^{\circ} \mathrm{C}$, respectively.

There was nearly a fourfold increase in ${ }^{14} \mathrm{C}$-picloram translocation to the roots when plants were maintained at a cool $\left(12^{\circ} \mathrm{C}\right)$ compared to a warm $\left(30^{\circ} \mathrm{C}\right)$ constant temperature, regardless of depth (Table 3). For example, the amount of applied ${ }^{14} \mathrm{C}$-picloram translocated to the $0-$ to $4-\mathrm{cm}$ depth was 2.7 and $0.6 \%$ at a constant temperature of $12^{\circ}$ and $30^{\circ} \mathrm{C}$, respectively. Also, there generally was more ${ }^{14} \mathrm{C}$-picloram accumulation in roots preconditioned or treated at cooler compared to warmer temperatures at all depths.

A temperature change 24 hours before treatment had less effect on ${ }^{14} \mathrm{C}$-picloram translocation to leafy spurge roots as depth increased (Table 3). The percentage of applied ${ }^{14} \mathrm{C}$-picloram changed only by a factor of $0.02,0.01$, and 0.004 with each $1^{\circ} \mathrm{C}$ change in temperature at the $0-$ to $4-, 4-$ to $8-$, and $8-$ to $16-\mathrm{cm}$ depths, respectively. Picloram is exuded readily from roots near the soil surface (3), so only a small portion of applied herbicide is available at deeper depths for exudation.

Although the amount of ${ }^{14} \mathrm{C}$-picloram absorbed by leafy spurge increased as temperature increased, the percentage of absorbed ${ }^{14} \mathrm{C}$ that was translocated to the root system declined as temperature increased (Table 3). For example, when plants remained at $12^{\circ}$, $18^{\circ}, 24^{\circ}$, or $30^{\circ} \mathrm{C}$ during the entire experiment, $13.4,9.4,8.1$, and $3.6 \%$ of the absorbed ${ }^{14} \mathrm{C}$-picloram translocated to the root system. Translocation of ${ }^{14} \mathrm{C}$-picloram to the roots generally was greatest when the herbicide was applied to plants maintained at $12^{\circ}$ or $18^{\circ}$ $\mathrm{C}$ and when the temperature declined 24 hours before treatment. Hickman et al. (3) found that ${ }^{14} \mathrm{C}$-picloram exudation in leafy spurge roots was not affected by temperature. Thus, the decline in ${ }^{14} \mathrm{C}$-picloram concentration at warmer compared to cooler temperatures was likely due to less herbicide translocation and not to an increase in picloram exudation at warmer temperatures.

A decline in the amount of ${ }^{14} \mathrm{C}$-picloram translocated to the root from 4.3 to $1 \%$ or less of applied ${ }^{14} \mathrm{C}$ as the temperature 24 hours before application increased (Table 2) may account for the poor control occasionally obtained from picloram applied at the proper rate and growth stage. Also, picloram applied at high temperatures affects leafy spurge visibly within 4 to 6 hours after application (5), so rapid phytotoxic effects may further reduce translocation to the roots. A slight increase in the amount of picloram translocated to roots results in a large increase in leafy spurge control. For example, 2,4-D applied with ${ }^{14} \mathrm{C}$-picloram increased the amount of unmetabolized picloram reaching the root by less than $1 \%$ of applied ${ }^{14} \mathrm{C}$ but resulted in 20 to $30 \%$ increase in longterm control in the field (9). 
Table 3. Distribution of ${ }^{14} \mathrm{C}$-picloram in leafy spurge roots by depth preconditioned at various temperatures 96 and 24 hours before treatment.

\begin{tabular}{|c|c|c|c|c|c|c|}
\hline \multirow{2}{*}{$\begin{array}{l}\text { Root } \\
\text { depth }\end{array}$} & \multirow{2}{*}{$\begin{array}{l}\text { Initial } \\
\text { temperature }\end{array}$} & \multicolumn{5}{|c|}{$\begin{array}{l}\text { Absorption as affected by temperature }(\mathrm{C}) \\
24 \text { hours before to } 72 \text { hours after treatment }\end{array}$} \\
\hline & & 12 & 18 & 24 & 30 & Mean \\
\hline $\mathrm{cm}$ & $\mathrm{C}$ & 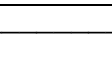 & 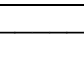 & f appli & 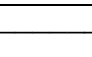 & Z \\
\hline \multirow[t]{4}{*}{0 to 4} & 12 & $2.7^{\mathrm{b}}$ & 1.6 & 1.0 & $\ldots$ & 1.8 \\
\hline & 18 & 1.8 & 1.6 & 2.9 & 2.2 & 2.1 \\
\hline & 24 & 1 & 0.9 & 1.5 & 1 & 1.1 \\
\hline & 30 & $\ldots$ & 1.5 & 0.5 & 0.6 & 0.9 \\
\hline \multicolumn{2}{|l|}{$\operatorname{LSD}(0.05)$} & 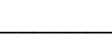 & & -1.4 & 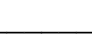 & \\
\hline \multicolumn{2}{|l|}{ Mean } & 1.8 & 1.4 & 1.5 & 1.3 & \\
\hline \multicolumn{2}{|l|}{ Regression } & \multicolumn{3}{|c|}{$Y=1.43+0.02 X^{\mathrm{c}}$} & \multicolumn{2}{|c|}{$\left(\mathrm{R}^{2}=0.61\right)$} \\
\hline \multirow[t]{4}{*}{4 to 8} & 12 & 0.75 & 0.68 & 0.73 & $\ldots$ & 0.72 \\
\hline & 18 & 0.53 & 0.49 & 0.32 & 0.51 & 0.46 \\
\hline & 24 & 0.20 & 0.26 & 0.26 & 0.16 & 0.22 \\
\hline & 30 & $\ldots$ & 0.25 & 0.13 & 0.10 & 0.16 \\
\hline \multicolumn{2}{|l|}{ LSD (0.05) } & & & $0.40-$ & & \\
\hline \multicolumn{2}{|l|}{ Mean } & 0.49 & 0.42 & 0.36 & 0.26 & \\
\hline \multicolumn{2}{|l|}{ Regression } & \multicolumn{3}{|c|}{$Y=0.39+0.01 X$} & \multicolumn{2}{|c|}{$\left(\mathrm{R}^{2}=0.87\right)$} \\
\hline \multirow[t]{4}{*}{8 to 16} & 12 & 0.8 & 0.6 & 0.5 & $\ldots$ & 0.6 \\
\hline & 18 & 0.5 & 0.5 & 0.7 & 0.3 & 0.5 \\
\hline & 24 & 0.3 & 0.4 & 0.3 & 0.2 & 0.3 \\
\hline & 30 & $\ldots$ & 0.4 & 0.2 & 0.2 & 0.3 \\
\hline \multicolumn{2}{|l|}{$\operatorname{LSD}(0.05)$} & & & 0.5 & & \\
\hline \multicolumn{2}{|l|}{ Mean } & 0.5 & 0.5 & 0.4 & 0.2 & \\
\hline \multicolumn{2}{|l|}{ Regression } & \multicolumn{3}{|c|}{$Y=0.41+0.004 X$} & \multicolumn{2}{|c|}{$\left(\mathrm{R}^{2}=0.36\right)$} \\
\hline 0 to 16 & 12 & 13.4 & 6.1 & 6.9 & ... & 8.8 \\
\hline \multirow[t]{3}{*}{ Total } & 18 & 12.0 & 9.4 & 10.7 & 6.5 & 9.7 \\
\hline & 24 & 10.0 & 8.3 & 8.1 & 5.5 & 8.0 \\
\hline & 30 & $\ldots$ & 9.3 & 3.9 & 3.6 & 5.6 \\
\hline \multicolumn{2}{|l|}{$\operatorname{LSD}(0.05)$} & & & $-4.4-$ & 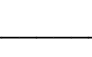 & \\
\hline \multicolumn{2}{|l|}{ Mean } & 11.8 & 8.3 & 7.4 & \multicolumn{2}{|l|}{5.2} \\
\hline Regression & \multicolumn{4}{|c|}{$\mathrm{Y}=8.11+-0.11 \mathrm{X}$} & \multicolumn{2}{|c|}{$\left(\mathrm{R}^{2}=0.85\right)$} \\
\hline
\end{tabular}

${ }^{a}$ Temperature during a 72-hour period from 96 hours to 24 hours before treatment.

${ }^{b}$ Bold numbers indicate a constant temperature throughout the experiment.

${ }^{\mathrm{c}}$ Degree temperature change 24 hours before treatment.

Picloram absorption and translocation were similar in treatments at 18 or $30^{\circ} \mathrm{C}$ in previous research (11). However, in that study, herbicide was applied immediately before the temperature change. There seems to be a lag phase between when the temperature changes and the physiology of the plant adjusts, resulting in changes in ${ }^{14} \mathrm{C}$-picloram ab- 
sorption and translocation. Temperature may influence the penetration of herbicides through plant surfaces by inducing physical changes in the cuticular layer of the leaf (13). Thus, the difference in response to temperature between this research and the previous report may be due in part to the time required for changes to occur in the cuticular wax (14).

Picloram application during warm temperatures, especially when the temperatures were continuing to increase, maximized absorption and movement to the foliage, but maximum translocation to the roots occurred at the coolest temperature $\left(12^{\circ} \mathrm{C}\right)$ evaluated (Table 1). Many other factors contribute to herbicide absorption and translocation in plants, including moisture stress, growth stage, and humidity. The optimum application timing for picloram on leafy spurge seems to be during the true-flower growth stage with high humidity $(7,11)$ and with warm temperatures to increase absorption followed by cool temperatures to increase translocation to the roots.

\section{Literature cited}

1. Alley, H. P. and C. G. Messersmith. 1985. Chemical control of leafy spurge. Pages 65-78 in A. K. Watson, ed. Leafy Spurge. Monogr. 3 Weed Sci. Soc. Am., Champaign, IL 61820.

2. Brady, H. A. 1970. High temperature boosts 2,4,5-T activity in woody plants. Proc. South. Weed Sci. Soc. 23:234-236.

3. Hickman M. V., C. G. Messersmith, and R. G. Lym. 1990. Picloram release from leafy spurge roots. J. Range Manage. 43:442-445.

4. Darwent, A. L. and R. Behrens. 1972. Effect of pretreatment environment on 2,4-D phytotoxicity. Weed Sci. 20:540-544.

5. Lym, R. G. and C. G. Messersmith. 1983. Control of leafy spurge with herbicides. N.D. Farm Res. 40(5):16-19, 26.

6. Lym, R. G. and C. G. Messersmith. 1985. A summary of leafy spurge control in North Dakota since 1963. N.D. Farm Res. 43(1):3-9, 14.

7. Lym, R. G. and C. G. Messersmith. 1985. Leafy spurge control with herbicides in North Dakota: 20-year summary. J. Range Manage. 38:149-154.

8. Lym, R. G. and C. G. Messersmith. 1987. Carbohydrates in leafy spurge roots as influenced by environment. J. Range Manage. 40:139-144.

9. Lym, R. G. and K. D. Moxness. 1989. Absorption, translocation, and metabolism of picloram and 2,4-D in leafy spurge (Euphorbia esula). Weed Sci. 37:498-502.

10. Morton, H. L. 1966. Influence of temperature and humidity on foliar absorption, translocation, and metabolism of 2,4,5-T by mesquite seedlings. Weeds 14:136-141.

11. Moxness, K. D. and R. G. Lym. 1989. Environment and spray additive effects on picloram absorption and translocation in leafy spurge. Weed Sci. 37:181-186.

12. Richardson, R. G. 1977. A review of foliar absorption and translocation of 2,4-D and 2,4,5-T. Weed Res. 17:259-272.

13. Sargent J. A. 1965. The penetration of growth regulators into leaves. Annu. Rev. Plant Physiol. $16: 1-12$.

14. Sharma, M. P. and W. H. Vanden Born. 1970. Foliar penetration of picloram and 2,4-D in aspen and balsam poplar. Weed Sci. 18:57-63.

Page 8 of 8 